\title{
MIKROBIOLÓGIAI GYORSTESZTEK ALKALMAZHATÓSÁGA SZÜRKEVIZEK VIZSGÁLATA SORÁN
}

\section{USABILITY OF MICROBIOLOGICAL RAPID TESTS FOR GREYWATER ANALYSIS}

\author{
Petrányi Andrea ${ }^{1}$, Fórián Sándor ${ }^{2}$, Boros Norbert ${ }^{3}$ \\ ${ }^{1,2,3}$ Debreceni Egyetem Müszaki Kar Környezet-és Vegyészmérnöki Tanszék, 4028, \\ Magyarország, Debrecen, Ótemetö u. 2-4. \\ landi.petranyi@gmail.com \\ 2forian@eng.unideb.hu \\ 3 nboros@eng.unideb.hu
}

\begin{abstract}
The drinking water consumption in households can be considerably reduced by greywater recycling. To determine the reusability of greywater we have to specify its main physical, chemical and microbiological parameters. We found that the mean of total plate count in greywater was $4.8 \operatorname{logCFU~ml^{-1}}$ and among the different greywater sources in laundry water was the highest $\left(5.3 \log C F U \mathrm{ml}^{-1}\right)$. E. coli contamination was significant in bath water samples: $0.8 \log \mathrm{CFU} \mathrm{m}{ }^{-1}$. During storage for 48 hours the dissolved oxygen demand reduced with $30 \%$, while turbidity increased slightly. The increase of total plate count was nearly an order of $\log \mathrm{CFU} \mathrm{ml} \mathrm{m}^{-1}$ per 12 hours. Based on our results we can say that microbiological load is well definable by microbiological rapid tests.
\end{abstract}

Keywords: greywater, microbiological tests, storage.

\section{Összefoglalás}

A szürkevizek hasznosításával jelentős mértékben csökkenthető a háztartások ivóvíz-felhasználása. Az újrahasznosíthatóság meghatározásához azonban fontos a szürkevizek egyes fizikai, kémiai és mikrobiológiai paramétereinek vizsgálata. Kutatásunk során megállapítottuk, hogy a szürkevizek össztelepszáma 4,8 lgCFU/ml, a vizsgált szürkevíz források közül a mosóvizekben volt a legmagasabb $(5,3 \mathrm{lgCFU} / \mathrm{ml})$. Az E. coli terheltség a fürdővíz minták esetén volt jelentős: $0,8 \mathrm{lgCFU} / \mathrm{ml}$. A 48 órás tárolás alatt a minták oldott szerves széntartalma 30\%-kal csökkent, míg ezzel egy időben a zavarosság kismértékben nőtt. Az össztelepszám a fürdővíz mintában közel egy nagyságrenddel nőtt 12 óránként. Az eredményeink alapján elmondható, hogy a mikrobiológiai gyorstesztekkel jól értékelhető az egyes minták mikrobiális terheltsége és e minőségi paraméter változása a tárolás során.

Kulcsszavak: szürkevíz, mikrobiológiai gyorstesztek, tárolás. 


\section{Bevezetés}

Szürkevíznek nevezünk minden fürdésből, mosásból, illetve mosogatásból származó szennyvizet. Megfelelő kezelés után e vizek újrahasználhatók, többek között WC öblítésére vagy kertek öntözésére [1].

Az újrahasznosításra szánt szürkevíznek meg kell felelni bizonyos elvárásoknak, melyet elsősorban higiéniai, esztétikai és környezeti szempontok határoznak meg.

A szürkevizek tartalmazhatnak patogén kórokozókat (baktériumok, vírusok), melyek egészségügyi veszélyt jelenthetnek az újrahasználat során $[2,3]$. A legtöbb szakirodalom az alábbi mikroorganizmusokat említi, mint potenciális veszélyforrásokat: Escherichia coli, Salmonella ssp., Pseudomonas aeruginosa, Staphylococcus aureus és egyes vírusok $[4,5]$.

A vizekben jelenlévő kórokozókat számos módszerrel meghatározhatjuk. Gyakori vizsgálati módszer a Petri-csészében, szélesztéssel történő tenyésztés, de emellett számos más vizsgálati módszer is ismert. Gyakran szükség van gyorsabb eredményekre, föként az élelmiszeripar és a humán gyógyászat számára.

$\mathrm{Az}$ MPN (most probable number=legvalószínűbb szám) módszer lényege, hogy a mikrobákat szelektív, folyékony táptalajban szaporítjuk, és a mikrobaszaporodást mutató csövek száma alapján, statisztikai úton következtetünk a keresett mikroorganizmusok számára [6]. E módszerrel a koliform és $E$. coli baktériumok egyidejűleg meghatározhatóak.

Membránszüréssel történő meghatározás során adott mennyiségü mintát $0,45 \mu \mathrm{m}$ pórusátmérőjü membránszürőn átszívatunk. A szürőlapot szelektív táptalajra helyezve tenyészthetők a vizsgálni kívánt mikroorganizmusok [7]. Az eredményt koliform baktériumok esetén 24 órás inkubálás után kapjuk meg $100 \mathrm{ml}$ mintára vonatkoztatva.
A mikrobiológiai gyorstesztek előnye, hogy nem igényelnek mikrobiológiai laboratóriumi hátteret. A tesztek 2 táptalajt tartalmaznak, a mintavétel a tesztek folyadékba merítésével vagy szilárd felszínhez nyomva történik [8].

E tanulmányunkban az általunk használt Hygiene Monitor gyorstesztek alkalmazhatóságát vizsgáltuk szürkevizek mikrobiológiai minőségének meghatározására. Továbbá célunk volt a mikrobiális terheltség és az oldott szerves anyag tartalom közötti összefüggések vizsgálata az egyes szürkevíz források esetén, illetve a 48 órás tárolás ideje alatt.

\section{Anyag és módszer}

A szürkevíz mintákat Debrecen különböző háztartásaiból gyüittöttük, fürdésböl, mosásból és mosogatásból.

Mértük az általános fizikai-kémiai paramétereket, mint hőmérséklet, $\mathrm{pH}$, fajlagos elektromos vezetőképesség, (Multiline P4 mérőbörönd, WTW GmbH, Germany), a zavarosságot (Turb 555-IR, WTW GmbH, Germany), illetve az oldott szerves széntartalmat (Shimadzu TOC- $\mathrm{V}_{\mathrm{CPN}}$, Shimadzu Corporation, Japan).

A mikrobiológiai terheltséget Hygiene Monitor (Transia GmbH, Germany) gyorstesztekkel határoztuk meg. Két kombinált gyorstesztet alkalmaztunk, melyekkel az össztelepszámot, az összes koliform, illetve E. coli telepek mennyiségét adtuk meg. Az egyes teszteknél az inkubációs idő 24 és 72 óra, az inkubációs hőmérséklet mindkét vizsgálat során $37^{\circ} \mathrm{C}$ volt.

A tárolás során végbemenő változások vizsgálatához 10 fürdővíz és 10 mosóvíz mintából készítettünk 2-2 1 elegyet, melyeket $20^{\circ} \mathrm{C}$-on, sötét helyen tároltunk. 12 óránként vizsgáltuk a tárolás hatására bekövetkező változásokat a fizikai-kémiai és a mikrobiológiai paramétereken. 


\section{Eredmények és értékelésük}

Az 1. táblázatban bemutatott eredmények alapján elmondhatjuk, hogy mind az össztelepszám, mind a koliform baktériumok száma a mosóvíz mintákban volt a legmagasabb, 5,3 és 4,1 lgCFU/ml. Az $E$. coli mennyisége viszont a fürdővizekben volt kiemelkedő, $0,8 \operatorname{lgCFU} / \mathrm{ml}$.

Megfigyelhető, hogy a csapvíz minták is tartalmaztak kis mennyiségben mikroorganizmusokat, össztelepszámuk 2,3 lgCFU/ml volt.

A szürkevizek átlagos össztelepszáma $4,8 \mathrm{lgCFU} / \mathrm{ml}$ volt.

1. táblázat. Szürkeviz és csapvíz minták mikrobiológiai eredményei $(\mathrm{lgCFU} / \mathrm{ml})$

\begin{tabular}{|c|c|c|c|c|}
\hline \multicolumn{2}{|c|}{ Típus } & $\begin{array}{c}\text { Össztele } \\
\text { p-szám }\end{array}$ & $\begin{array}{c}\text { Kolifor } \\
\mathrm{m}\end{array}$ & $\begin{array}{c}\text { E.col } \\
i\end{array}$ \\
\hline $\begin{array}{c}\text { Csapvíz } \\
(\mathrm{n}=12)\end{array}$ & Átlag & 2,3 & 0,3 & 0,0 \\
\cline { 2 - 5 } & Szórás & 1,1 & 0,8 & 0,0 \\
\hline $\begin{array}{c}\text { Fürdővíz } \\
(\mathrm{n}=16)\end{array}$ & Átlag & 4,6 & 3,3 & 0,8 \\
\cline { 2 - 5 } & Szórás & 0,7 & 1,2 & 1,2 \\
\hline $\begin{array}{c}\text { Mosóvíz } \\
(\mathrm{n}=14)\end{array}$ & Átlag & 5,3 & 4,1 & 0,4 \\
\cline { 2 - 5 } & Szórás & 1,0 & 1,4 & 0,9 \\
\hline $\begin{array}{c}\text { Mosogatóví } \\
\mathrm{z}(\mathrm{n}=13)\end{array}$ & Átlag & 4,6 & 3,2 & 0,2 \\
\cline { 2 - 5 } & Szórás & 1,2 & 1,7 & 0,6 \\
\hline \multirow{2}{*}{$\begin{array}{c}\text { Szürkevíz- } \\
\text { átlag } \\
(\mathrm{n}=43)\end{array}$} & Átlag & 4,8 & 3,5 & 0,4 \\
\cline { 2 - 5 } & Szórás & 1,0 & 1,5 & 1,0 \\
\hline
\end{tabular}

A 2. táblázatban bemutatott adatok alapján megfigyelhető, hogy a mosóvizek átlagos pH-ja volt a legmagasabb $(8,3)$, míg a fürdő- és mosogatóvizeké közel azonos. Az átlagos zavarosság értékek között nagy különbségeket tapasztaltunk, míg a fürdővizekben 24,8 NTU, a mosó- és mosogatóvizekben ennek többszöröse, 181,2 és 332,6 NTU volt. A vezetőképesség szintén a mosóvizek esetén volt a legmagasabb, ezzel szemben a fürdővizekben a csapvízhez közeli értéket mértünk.

2. táblázat. Szürkeviz minták fizikai jellemzői

\begin{tabular}{|l|l|l|l|}
\hline \multicolumn{1}{|c|}{ Típus } & $\mathrm{pH}$ & $\begin{array}{l}\text { Zavarosság } \\
(\mathrm{NTU})\end{array}$ & $\begin{array}{c}\text { Vez. } \\
\text { kép. } \\
(\mu \mathrm{S} / \mathrm{cm})\end{array}$ \\
\hline Csapvíz & 7,4 & 0,3 & 537,1 \\
\hline Fürdővíz & 7,5 & 24,8 & 565,5 \\
\hline Mosóvíz & 8,3 & 181,2 & 1836,2 \\
\hline Mosogatóvíz & 7,6 & 332,6 & 1348,8 \\
\hline $\begin{array}{l}\text { Szürkevíz- } \\
\text { átlag }\end{array}$ & 7,7 & 141,7 & 1064,7 \\
\hline
\end{tabular}

A mosó- illetve mosogatóvíz mintákban mértük a legmagasabb szerves anyag tartalmat, DOC értékük 301 és 305 mg/l. Ezen szürkevíz típusokban magas össztelepszám volt kimutatható, 5,3 és 4,6 lgCFU/ml (1. ábra).

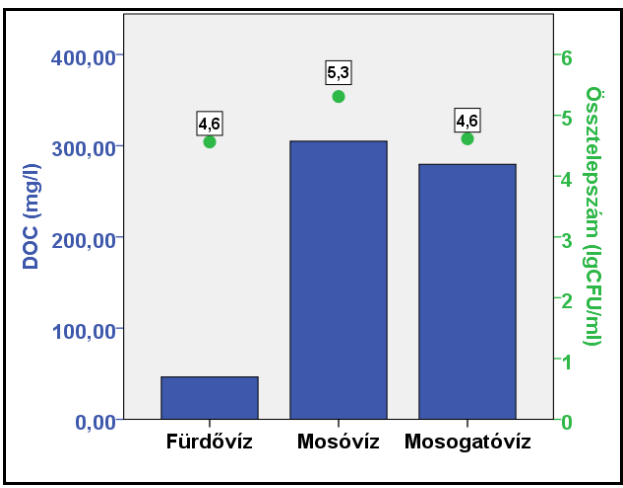

1. ábra. Szürkeviz típusok össztelepszáma és DOC értéke

Ugyanez azonban nem mondható el a fürdővizekről, melyek össztelepszáma szintén 4,6 $\mathrm{lgCFU} / \mathrm{ml}$, azonban oldott szerves széntartalma jóval alacsonyabb, $50 \mathrm{mg} / \mathrm{l}$ körül volt. Az alacsony szerves anyag tartalom tehát nem feltétlenül jelenti azt, hogy alacsony a mikrobiális terheltsége a vizsgált mintának. 
A 48 órás tárolás ideje alatt megfigyeltük, hogy a pH mindkét szürkevíz esetén csökkent, mosóvízben 9,0-ről 8,0-ra, fürdővíz esetén pedig 7,7-ről 7,3-ra. A DOC értékében $30 \%$ csökkenést tapasztaltunk mindkét szürkevízben, míg a zavarosság kismértékben növekedett a mintákban.

A 2. ábrán a fürdővíz minta össztelepszámának és DOC tartalmának változása látható. A fürdővíz össztelepszáma 12 óránként közel egy nagyságrenddel nőtt, 4 lgCFU/ml-ről 7 lgCFU/ml-re. A mikrobák számának növekedése az oldott szerves széntartalom csökkenését okozta.

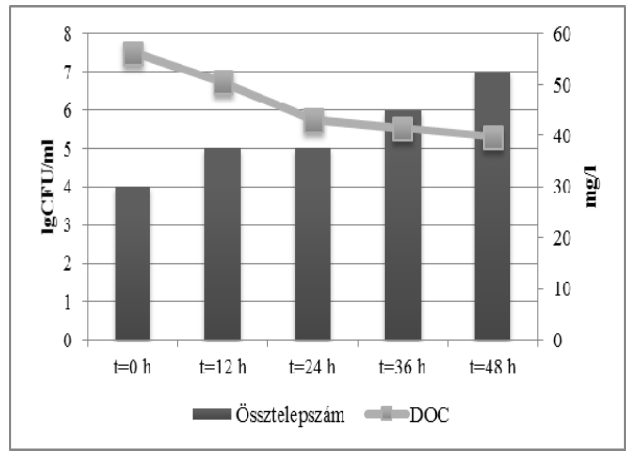

2. ábra. Össztelepszám és DOC változása a tárolás alatt fürdöviz esetén

\section{Következtetések}

A mikrobiológiai gyorstesztekkel végzett vizsgálatok tapasztalatai alapján megállapítható, hogy az általunk használt tesztek könnyen használhatóak és alkalmasak mikrobiális szennyezettség kimutatására. A tesztek eredményei alapján nagyságrendileg értékelhető az egyes forrásokból származó szürkevíz minták terheltsége. Az előbb említett elönyök mellett azonban tisztában kell lennünk azzal, hogy ezen tesztek eredményeinek a megbízhatósága korlátozott és mindenképpen szükséges a mikrobák hagyományos táptalajon való tenyésztése is.

\section{Köszönetnyilvánítás}

$\mathrm{Az}$ analitikai vizsgálatok elvégzését a TÁMOP-4.2.2.A-11/1/KONV-2012-0041 számú projekt támogatta. A projekt az Európai Unió támogatásával, az Európai Szociális Alap társfinanszírozásával valósult meg.

\section{Szakirodalmi hivatkozások}

[1] do Couto, E.A., Calijuri, M.L., Assemany, P.P., Santiago, A.F., Carvalho, I.C.: Greywater production in airports: Qualitative and quantitative assessment, Resources, Conservation and Recycling, 2013, 77, 44-51.

[2] O’Toole, J., Sinclair, M., Malawaraarachchi, M., Hamilton, A., Barker, S.F., Leder, K.: Microbial quality assessment of household greywater, Water Research, 2012, 46, 43014313.

[3] Boros, N., Petranyi, A., Kocsis, D., Bodnár, I.: Characterization of greywater sources on the base of organic content and microbial quality, International Review of Applied Sciences and Engineering, 2014, 35-40.

[4] Cogan, T. A., Bloomfield, S. F., Humphrey, T. J.: The effectiveness of hygiene procedures for prevention of cross-contamination from chicken carcasses in the domestic kitchen, Letters in Applied Microbiology, 1999, 29, 354-358.

[5] Maimon, A., Friedler, E., Gross, A.: Parameters affecting greywater quality and its safety for reuse, Science of Total Environment, 2014, 487, 20-25.

[6] Deák, T.: Élelmiszer-mikrobiológia, Mezőgazda Kiadó, Budapest, 2009.

[7] MSZ EN ISO 9308-1:2001

[8] TRANSIA GmbH Germany: Hygiene Monitor für die mikrobiologische Hygieneuntersuchung, Dieselstraße 9A - 61239 OberMörlen. 